\title{
Editor's Introduction
}

\section{Fernando Espada}

\author{
Save the Children; F.Espada@savethechildren.org.uk
}

After three special issues of the Journal of Humanitarian Affairs - on humanitarianism and the end of liberal order, humanitarian security and humanitarian innovation - the first regular issue includes a range of articles touching on questions that at the time of writing are largely off the radar of global public attention. When the journal's editorial board compiled the contributions to this issue, it could not have foreseen the first pandemic of the twenty-first century: Covid-19.

The same eyes that now frantically pore over graphs showing the evolution of coronavirus cases in real time were not long ago scanning Twitter feeds in dread of the moment when US President Donald Trump would make good on his promise to unleash 'fire and fury like the world has never seen'. Fortunately for life on earth, two summits, a 'very beautiful letter' to Trump from Kim Jong Un and a brief encounter between the two leaders in the Korean Demilitarised Zone appear to have delayed the moment of truth. However, as Nazanin ZadehCummings and Lauren Harris explain in 'The Impact of Sanctions against North Korea on Humanitarian Aid', the apparent détente between Washington DC and Pyongyang is not experienced by humanitarian agencies working in North Korea. Threats of mutual obliteration have given way to a slower process of asphyxia by bureaucratic impediments, mostly related to sanctions by the UN Security Council and the US government, on top of North Korea's restrictions.

Ideally, all actors (whether aid organisations or not) responding to a crisis should share similar - or at least compatible - goals and respect each other's mandates. However, this is something that doesn't happen in North Korea and that only presents mixed results in the socalled civil-military coordination in humanitarian responses. The challenge for humanitarian agencies to work effectively and according to their missions and principles while cohabitating the same spaces (geographical and others) as military and non-state armed actors has been a headache for decades. Contexts of violent conflict are usually examples of all that can go wrong when civil-military coordination is not prioritised. But those are not the only contexts where humanitarian agencies struggle to find and protect their space vis-à-vis military actors. The Indicator Framework that Vincenzo Bollettino and Birthe Anders present in 'Civil-Military Coordination: A Framework for Measuring Effectiveness in Humanitarian Response' addresses the need for a practical tool in that area.

A fascinating aspect of current efforts to tackle the Covid-19 pandemic is the visible decoupling between official messaging and the reality of practices on the ground. The United States has been flagged as an example of the disconnect between the ungrounded discourse emanating from the headquarters (i.e. the White House and Capitol Hill) and the grim reality reported by those in the field (for example, the New York governor's daily briefings) in dealing with the coronavirus epidemic. Surely, there are many other countries experiencing this; but when it comes to managing risk security risks in particular - it does matter where you sit in the equation. This big disconnect is the focus of Julia Brooks and Rob Grace in 'Confronting Humanitarian Insecurity: The Law and Politics of Responding to Attacks against Aid Workers'. Official statements produced in humanitarian agency headquarters present humanitarian principles and acceptance as inherently linked. The everyday practice of humanitarian staff on the ground is more reflective of the inevitability of having to find acceptable compromises to stay safe. A Hegelinspired synthesis of headquarters thesis and field office antithesis could offer a possible solution to the everpresent tension of how to manage security within humanitarian organisations.

In another contribution to this issue, Logan Cochrane's 'Synthesis of Evaluations in South Sudan: Lessons Learned for Engagement in Fragile and ConflictAffected States' sheds light on the complexity of working in fragile and conflict-affected contexts. However, complexity is not just an assessment of the reality that leads to a positive action. As the global and national response to the sequence of Covid-19 outbreaks has shown, complexity often triggers an opposite reaction - sometimes

\section{MANCHESTER} 1824

Manchester University Press 
unconscious, sometimes deliberate - not to fully engage with reality and the individual and collective responsibility of tackling the challenges in front of us. Cochrane's synthesis identifies a considerable gap between what is known and what is done as a result of that knowledge.

Closing borders and curtailing the movement of people is becoming key to government containment of Covid-19. Epidemiologists don't take these measures lightly, as they know well that stopping people from moving around is, after a while, mission impossible. Governments, on the other hand, are often keener to decide who can move and who has to stay put. Klaus Neumann's account of hostile and hospitable reactions to the arrival of asylum seekers and migrants in Europe and to the actions of some nongovernmental organisations in 'The Appeal of Civil Disobedience in the Central Mediterranean: German Responses to the June 2019 Mission of the Sea-Watch 3' is an important reminder that human dignity does not make sense if it's circumscribed by geographical borders. Neumann also reminds us that many citizen and grass roots organisations were ready to disobey their government's narrow interpretation of who is entitled to what rights - which suggests that the motivations of organisations like Sea-Watch should not be seen as mere gestures of hospitality towards migrants.

In 'Myths of Violence', Brad Evans offers a possible explanation of what motivates solidarity with migrants and asylum seekers in Europe. For Evans, instead of the privilege of absolute power, violence is the outcome of asymmetric freedom, 'the freedom to punish and destroy ... over the freedom to resist or ... to flee'. With reference to Gilles Deleuze, he argues that oppression not only denies the rights of the oppressed but restricts their movement. He challenges a conception of 'the political' that he feels legitimises the continuation of violence in multiple forms. According to this conception, violence, caused by difference, can only be managed. But, for Evans, attempts at homogenisation produce violence, not difference per se. If difference is no longer seen as a problem, violence can be overcome.

Hopefully, someone will have already started planning the recovery phase after the Covid-19 disaster, particularly in developing countries. The virus won't directly destroy houses and buildings, but the lessons learned and those still to be learned - by the humanitarian shelter sector that Bill Flinn discusses in 'Defining 'Better' Better: Why Building Back Better Means More Than Structural Safety' might help ensure safer conditions for most people, instead of safe for fewer.

This regular issue ends with a response from Anna Skeels to the Journal of Humanitarian Affairs special issue on humanitarian innovation (JHA, 1:3). In 'From Black Hole to North Star' she defends a more positive view of the evolution of humanitarian innovation, its theory and practice. Skeels rightly argues that 'systemwide issues need system-wide collaboration'. Right now, this call is clearly of global relevance, not only for those involved with humanitarian innovation. 